\section{French research and development gets the boost it was promised}

\section{Paris}

As is the custom, French ministers have been told before the summer recess how much money they will have to spend next year. While some minsters will be disappointed, minister for research and technology Hubert Curien started his vacation a happy man, with $\mathrm{FF} 3,000$ million (\$484 million) more in his purse for 1989 than for the current year. This increase, of over 7.6 per cent, is way ahead of inflation (2.6 per cent) and confirms the new government's determination to give high priority to research and higher education.

An increase in spending was certain. Shortly after the May elections, Curien was given part of a FF1,200 million 'advance' to pull the academic community out of the doldrums it felt itself to be in as a result of the previous government's cuts (see Nature 333, 584; 1988). Under Prime Minister Jacques Chirac, research spending in 1987 and 1988 was allowed to fall in real terms, and jobs were lost, with a promise that the private sector would be helped to make up the difference.

The new Prime Minister Michel Rocard has been given full rein not only to reverse this downward trend, but to try to approach the 3 per cent of gross domestic product (GDP) for research that François Mitterrand once promised by the end of the decade. With current spending at 2.26 per cent of GDP, France lags slightly behind the United Kingdom and West Germany and it now seems unlikely that the target will be reached by 1990 .

Curien, who was given his own ministry in Rocard's second government, has also regained control of the research budgets of some other ministries, such as industry. This combined civil research and development budget (BCRD) is felt to allow better management of the nation's civil research spending, but was abandoned by the previous government, which lumped defence and civil research spending together. It is the BCRD that has increased by 7.6 per cent, to FF42,300 million.

Although the 1989 budget reflects Mitterrand's election promises, with education also receiving a FF11,000 million ( 5.5 per cent) boost, it is considered a 'one-off.' The government wants, next year, to reinstate the socialists' previous policy of long-term, statutory budget programmes for education and research which will underwrite a net annual progression. This, they hope, will avoid the 'accordion' effects of boosts and cuts experienced with changes of government over the past ten years. This has particularly affected higher education and research jobs where substantial new recruitments are now necessary to offset a spate of retirements in the early 1990 s.

If job creation is one of Curien's priorities, with 900 new researcher, technician and administrator posts expected for 1989 - compared to cuts last year - stronger links with industry are another. Earlier this month, Curien unveiled a programme, with FF120 million to spend this year, for collaboration between industry and public sector research. The programme aims to stimulate 'technology leaps' in French industry, with purification and manufacture of recombinant proteins one of the two priorities named so far. Peter Coles

\section{South Africa keeps them guessing}

Oxford

A FURTHER round of talks on the possibility of South Africa signing the Nuclear NonProliferation Treaty ended inconclusively in Vienna last week. South Africa's Minister of Foreign Affairs Pik Botha met Soviet, US and British officials for discussions before the general assembly of the International Atomic Energy Agency (IAEA) next month, where there is almost certain to be a renewed bid to expel South Africa (see Nature 334, 464; 1988). Botha stated afterwards that the South African government was still considering the implications of signing the treaty.

Botha also took the opportunity to engage in some characteristic sabre-rattling, declaring that his government had "the capability to make the bomb should we want to". When asked if South Africa already had nuclear weapons, he declined to enlarge on his statement. That South Africa has weapons capability is no major revelation, although this is the first time that it has been suggested at cabinet level by a member of the present government. Botha's statement differs from one made by former South African prime minister John Vorster in 1976 only in that it omits a rider about the country's intentions. Vorster said: "We are only interested in the peaceful applications of nuclear power. But we can enrich uranium, and we have the capability. And we did not sign the nuclear nonproliferation treaty."

Botha claimed further that the IAEA director-general, Hans Blix, is biased against South Africa over curbs on the spread of nuclear weapons. "I believe that Dr Blix doesn't want us to be part of the agency", he declared. Blix has denied this, saying that the agency would inspect South African nuclear facilities in exactly the same way as it checks plants in other member states Michael Cherry

\section{Towards caring not curing}

\section{London}

A REVOLUTION in medical education was set in motion last week at a five-day conference in Edinburgh, Scotland, organized by the World Federation for Medical Education (WFME). The outcome of the conference, a strategy document called The Edinburgh Declaration, outlines radical changes in training in medicine. The declaration recommends more emphasis on community health and preventative medicine in a reversal of the present bias towards hospital-based training and curative medicine. In a pre-conference document, the WFME says that as teachers are becoming more specialized, medical curricula are becoming increasingly compartmentalized; and training, instead of being focused on the community is focused on the hospital bed. As a result, "It is not surprising if medical students emerge with great regard for high technology and the most recent knowledge, low regard for less dramatic elements of health promotion, prevention of disease and caring rather than curing".

The conference was held in collaboration with the World Health Organisation and the United Nations Children's Fund among others, and was attended by representatives of universities, ministries of health and education and funding institutions such as the World Bank and the Rockefeller Foundation.

The declaration emphasizes that since there will have to be legislative changes, political will is necessary for reform to succeed. "The endorsement of the declaration by governments is "absolutely vital", says Walton. The first of six consultations with ministers will be a European conference in Portugal in November. These consultations should all be completed before the declaration goes before the World Health Assembly in 1989.

The cost of the reforms will be met by international funding agencies and coordinated via a new institute in Edinburgh. But Walton says no difficulties of cost are envisaged; nor of infrastructure. The only obstacle to implementation of the reforms, he says, will be the "entrenched attitudes of medical institutions".

But change will come about since it is being instigated from within the profession and not forced on it from without. "Everybody has wanted these reforms for decades," says Walton. And he says half of them could be introduced immediately.

The new director-general of the Worid Health Organisation, Dr Hiroshi Nakajima, pledged his full support for the declaration. "Technological excellence must not be an end in itself for the medical profession," he said. Christine McGourty 